DOI https://doi.org/10.30525/978-9934-26-182-4-41

\title{
ЗМІНИ ЕЛЕМЕНТНОГО СКЛАДУ ПЕЧІНКИ \\ ТА НИРКОВОЇ ТКАНИНИ ЕКСПЕРИМЕНТАЛЬНИХ ТВАРИН ЗА УМОВ НІТРАТНОЇ ІНТОКСИКАЦЇ̈
}

\author{
Нечитайло Л. Я. \\ кандидат біологічних наук, \\ асистент кафедри біологічної та медичної хімії \\ імені академіка Г. О. Бабенка \\ Івано-Франківський начіональний медичний університет
}

Кривов'яз О. С.

здобувач $P h D$,

асистент кафедри біологічної та медичної хімії

імені академіка Г. О. Бабенка

Івано-Франківський національний медичний університет

Нечитайло Н. О.

студентка кафедри біохімії та біотехнології

Прикарпатський національний університет імені Василя Стефаника м. Івано-Франківськ, Україна

Однією з медико-біологічних проблем останніх десятиліть $є$ насичення довкілля ксенобіотиками, що за певних умов стає причиною різних видів хімічної патології або ж призводить до збільшення загальної захворюваності внаслідок зниження стійкості організму. Значну небезпеку для людини серед хімічних забруднювачів у теперішній час становлять нітрати та нітрити. Допустиме добове споживання нітратів для людини не повинно перевищувати 5 мг на 1 кг маси тіла [1, с.2]. Нітрати, що використовують як мінеральні добрива, у найвищих концентраціях містяться в зелених овочах, але особливо небезпечні високі концентрації нітратів у питній воді [2, с.63 ]. Їх також використовуються як харчові добавки, при виробництві і консервуванні м'ясних і деяких рибних продуктів та при виготовленні лікарських засобів. [3, с.215]. Присутність нітратів у воді, їжі і кормах природне явище, проте при їх надходженні можливе утворення значно токсичніших (в 10-30 раз) сполук нітритів, які здатні трансформуватись у високотоксичні, мутагенні та канцерогенні нітрозаміни в грунті - рослинах - організмі людини і тварин. Відомо, що основним клінічним проявом дії нітратів в живому організмі є ураження травного 152 
каналу, серцево-судинної, дихальної та центральної нервової системи [4, с. 174]. Токсична дія нітратів та нітритів полягає в здатності активувати вільнорадикальні процеси, які можуть призводити до розвитку пухлинних процесів [5, с. 54], інгібування синтезу ДНК [6, с. 24], порушення функції ензимних систем [7, с. 151]. Окрім того, при гострих і важких отруєннях розвивається гемічна гіпоксія [8, с. 128]. При цьому в організмі людини та тварин виникають ураження практично всіх органів та тканин. Водночас, мало дослідженими залишається макро- та мікроелементний склад органів та тканин за умов ураження натрію нітратом, що має важливе значення для розуміння їх впливу на перебіг метаболічних процесів у живих організмах.

Враховуючи, надмірне забруднення навколишнього середовища нітратами та їхній небажаний вплив на організм, проблема вивчення їх токсичної дії, є особливо актуальною.

Метою даної роботи було дослідження вмісту есенціальних макро- та мікроелементів у нирковій тканині та печінці експериментальних тварин за умов нітратної інтоксикації.

Об'єктом дослідження були, білі безпородні статевозрілі щурі-самці масою 180-220 г, яких утримували в умовах віварію на стандартному раціоні.

Утримання тварин, їх харчування та маніпуляції проводилися 3 дотриманням етичних i законодавчих норм i вимог при виконанні наукових і біохімічних досліджень [9]. Моделями токсичного ураження тварин була інтоксикація натрію нітратом. Піддослідних тварин було поділено на дві групи: I - контрольна група, які отримували звичайну питну воду, II - дослідна група тварин, які отримували водний розчин натрію нітрату $\left(\mathrm{NaNO}_{3}\right)$ з питною водою в дозі $1 / 10 \mathrm{DL}_{50}$.Тварин виводили із експерименту під тіопенталовим наркозом на 1-, 14- та 28-у доби після завершення введення токсиканту. Рівень макро- та мікроелементів визначали в печінці та нирковій тканині дослідних тварин методом атомно-абсорбційної спектрофотометрії на спектрофотометрі С-115.

В даній роботі представлені результати дослідження впливу натрію нітрату на рівень макро- та мікроелементів в нирковій тканині та печінці експериментальних тварин. Зокрема, спостерігали підвищення рівня кальцію у печінці дослідних тварин впродовж всього періоду експерименту і на 28-му добу цей показник був вищим на $36 \%$ порівняно 3 контрольною групою тварин.

У нирковій тканині вміст кальцію поступово зростав і на завершення експерименту в 1,2 рази перевищував показники контрольних тварин. 


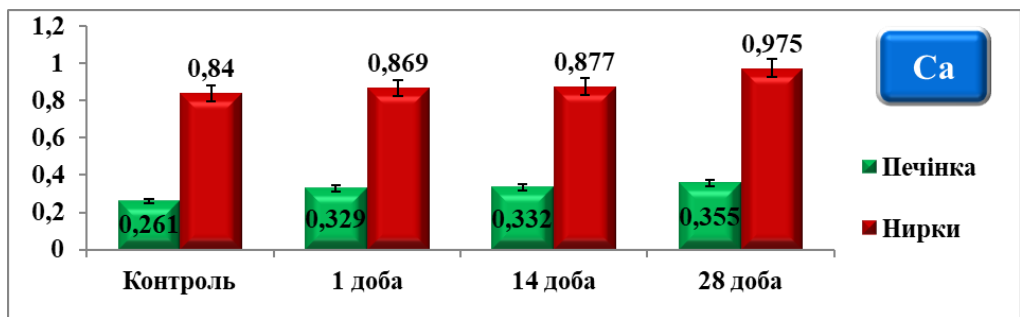

\section{Рис. 1. Вміст кальцію (мг/г) в нирковій тканині та печінці експериментальних тварин за умов нітратної інтоксикації}

Одночасно, вміст магнію змінювався іншим чином: у печінці концентрація даного елемента впродовж всього періоду спостереження була нижча відносно показників контрольної групи тварин. Найнижчий рівень магнію відмічено нами на 14-ту добу - на 50 \% нижче рівня контрольних тварин.

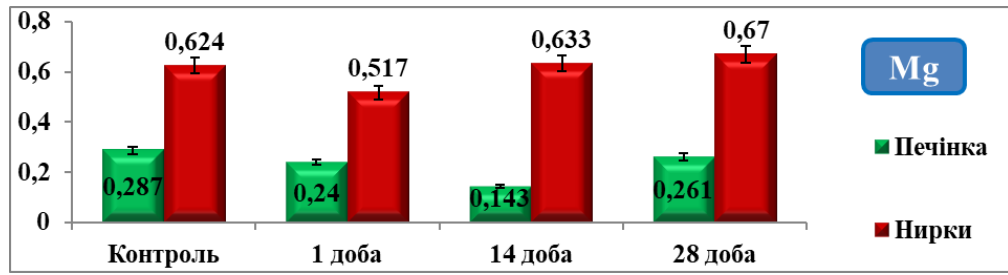

\section{Рис. 2. Вміст магнію (мг/г) в нирковій тканині та печінці} експериментальних тварин за умов нітратної інтоксикації

У нирковій тканині рівень магнію на 1-шу добу знижувався на $17 \%$, однак, на 14-ту і 28-му добу нітратної інтоксикації відмічено зростання на 1,5 - 7,4 \% порівняно з контролем.

Дослідження таких життєво важливих мікроелементів, як цинк i купрум, дозволило встановити: рівень цинку в печінці зростав в ранньому періоді експерименту на - на $11-28 \%$, але на 28-му добу знижувався і вміст його був нижчим за показники контрольної групи на 19,5\%.

Динаміка вмісту цинку в нирковій тканині була іншою: в ранньому періоді цей показник вищий - на 11\%, ніж в контрольних тварин, на 14-ту добу знижувався на 17,8 \% порівняно 3 контрольною групою тварин, однак, на 28-му добу перевищував значення на $19 \%$. 


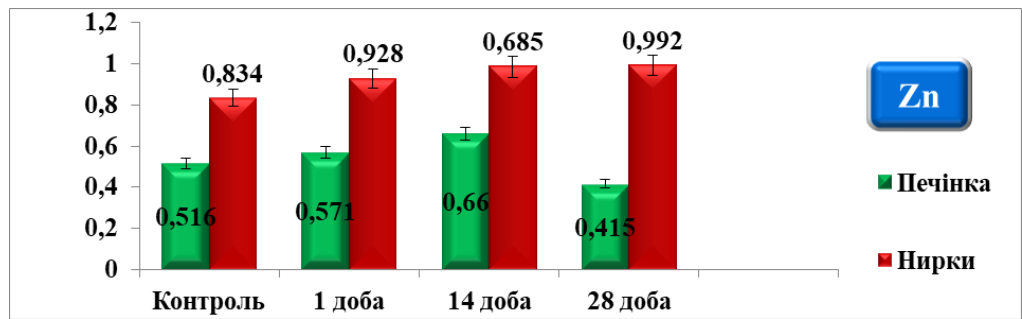

\section{Рис. 3. Вміст цинку (мг/г) в нирковій тканині та печінці експериментальних тварин за умов нітратної інтоксикації}

Аналіз одержаних результатів показав, що рівень купруму в печінці підвищувався впродовж всього періоду спостережень, однак, найбільшою мірою на 28-му добу - на 55 \% відносно контрольної групи тварин. У нирковій тканині концентрація купруму зростала на 14-ту добу на 25 \%, проте, на 28-му добу цей показник був на 6,5 \% нижче значень контрольної групи тварин.

Отримані нами експериментальні дані вказують на те, що надмірне поступлення нітратів призводить до підвищення рівня кальцію в печінці та нирках експериментальних тварин на тлі зниження іншого макроелементу - магнію в цих органах. Зміни рівня есенціальних мікроелементів - цинку та купруму в різних органах мають різноспрямований характер. Таким чином, нітратна інтоксикація зумовлює розвиток дисмікроелементозу, який супроводжується порушенням рівня макро- та мікроелементів у тканинах печінки та нирок уражених тварин.

\section{Література:}

1.Фіра Л.С, Лихацький П.Г. Вікові аспекти біохімічної оцінки ступеня інтоксикації за умов нітритного отруєння. Інформ. лист. 2015. № 128. C. $1-4$.

2. Гордієнко В. М., Рожков І.М. Здоров'я і нітрати: шляхи профілактики і зниження негативної дії. Спортивна медищина. 2007. № 1. C. $63-66$.

3.Приймак В. В. Екологічна оцінка вмісту нітратів у рослинній продукції. Таврійський науковий вісник. 2018. Вип. 101. - С. 215-219.

4. Луценко БО. Зміни окисного метаболізму у тканинах шлунка білих щурів за умов хронічної інтоксикації нітратом натрію. Вісн. Української мед. стоматол. академії. 2007. № 7(3). С.174-176.

5. Хміль Д. О., Міщенко А. В., Костенко В. О. Роль NO- синтази і аргініну у механізмах окисно-нітративного стрессу в шкірі щурів за умов 
надлишкового надходження в орагнізм нітрату натрію. Украӥнський журнал медицини, біологї та спорту. 2017. № 2 (4). С. 54-59.

6. Кузнецова ВЛ, Соловьева АГ. Оксид азота: свойства, биологическая роль, механизмы действия. Современ. пробл. науки и образов. 2015. № 4. C. 24-29.

7. Гунчак В.М., Гуфрій Д.Ф., Гутий Б.В., Васів Р.О. Вплив нітрату натрію у токсичних дозах на систему антиоксидантного захисту та перекисне окислення ліпідів у крові бугайців. Біологія тварин. 2010. T. 12, № 1. C. 151-158.

8. Стахурська I. О. Пришляк А. М. Інтенсивність метгемоглобінутворення у щурів різної статі за умови токсичного ураження натрію нітритом. Мед. хімія. 2014. Т. 16, № 3. С. 128.

9. Кожем'якін Ю.М., Хромов О.С., Філоненко М.А., Сейретдінова Г.А. Науково-практичні рекомендації з утримання лабораторних тварин та робіт із ними : Київ, 2002. 155 с. 